\title{
Innovations on measuring the indigenous population in the 2010 Brazilian Population Census
}

\author{
Nilza de Oliveira Martins Pereira \\ Brazilian Institute of Geography and Statistics, Avenida República do Chile, $7^{\circ}$. andar Rio de Janeiro, CEP \\ 20031-170, Brazil \\ Tel.: +55 21420345; E-mail: nilza.pereira@ibge.gov.br; nomp2008@hotmail.com
}

\begin{abstract}
The 2010 Brazilian Population Census, conducted by the Brazilian Institute of Geography and Statistics (IBGE), improved research of the indigenous population, introducing on its ethnic sense, but also the language spoken at home and geographical location, which are indigenous population criteria for identifying in censuses from different countries. The results potentially generated a great knowledge of the existing indigenous diversity in Brazil and a better understanding on the composition of this population segment. In 1991, the category "Indigenous" has been included as one of the options in the color/race question of the Brazilian national censuses. 1991 and 2000 censuses did not identify the each ethnic groups as only used as criterion the generic Indian, leaving to identify more than two hundred groups who inhabited the Brazilian territory. The "indigenous" previously raised by census 1991 and 2000 should not be used as a synonym and not as a substitute for "ethnic groups", of "indigenous groups" or "indigenous population", along the lines that predominate in the specialized anthropological literature. In 2010, for the first time in the history, IBGE provided a specific research of the census for the indigenous ethnic groups in the country.
\end{abstract}

Keywords: Census, indigenous, demography

\section{Introduction}

Methodological innovations have been introduced in the 2010 census aiming at rendering more visible the demographic characteristics of the indigenous populations. The Brazilian experience in the investigation of color data of the first census conducted in the country, in 1872. Table 1 shows of the question in censuses with a brief description in each census. Since 1991 Population Census, carried out by the Brazilian Institute of Geography and Statistics/IBGE systematically collect data the indigenous as a category color/race question in the sample questionnaire. In Brazil Census there are two types of questionnaires: the "basic" and "sample". All the questions in the basic questionnaire are also contained in the sample questionnaire, so that these common variables are investigated for all housing units and people. The 2010 Population Census introduced the question color/race, too, in the basic questionnaire, researched for all housing units and persons.
To capture data on the indigenous population, there are several criteria used by countries from the census source. In Latin America, the most used are selfidentification, languages spoken and geographic location [1]. The IBGE improved enhanced the investigation of this population group, introducing the collection of data about belonging to specific indigenous ethnic groups, but also the language spoken at home and the representation of the geographical location, that are indigenous population of identification criteria in national censuses in many countries.

It was possible to obtain information for ethnic groups, but also for the resident population, whether indigenous or not, on Indigenous Lands recognized in Brazil. In addition to these more general issues for all people who are indigenous to declare the question of color/race the 2010 Census implemented within Indigenous Lands and adequacy of other questions related to both housing unit characteristics as the individual, in order to better reflect the specificity of these groups [2]. 
Table 1

Indigenous the demographic census in Brazil

\begin{tabular}{|c|c|}
\hline Census date & Description of the question color/race \\
\hline 1872 & $\begin{array}{l}\text { Free taxed could autoclassificar between options: white, black, brown or caboclo (1), and it was his responsibility to classify } \\
\text { their slaves between two categories: black or brown }\end{array}$ \\
\hline 1880 & Census not realized \\
\hline 1890 & First survey conducted after the abolition of slavery in 1888. Categories: white, black, mestizo or caboclo (1) \\
\hline 1900 & Census not realized \\
\hline 1910 & No question regarding color/race \\
\hline 1920 & Census not realized \\
\hline 1930 & Census not realized \\
\hline 1940 & $\begin{array}{l}\text { Categories: black, white and yellow. The designation of browns were gathered under the disclosure, the indigenous who } \\
\text { recorded statements, caboclo (1), mulatto (2), mestizo, etc.). }\end{array}$ \\
\hline 1950 & Categories: white, black, yellow and brown \\
\hline 1960 & $\begin{array}{l}\text { Same categories of the } 1950 \text { census, with innovation being pre-coded in the questionnaires. the category "Indian" was } \\
\text { introduced in the question of color only to those living in villages or indigenous reserves }\end{array}$ \\
\hline 1970 & No question regarding color/race \\
\hline 1980 & Categories: white, black, yellow and brown \\
\hline 1991 & Categories: white, black, yellow, brown and indigenous \\
\hline 2000 & Categories: white, black, yellow, brown and indigenous \\
\hline 2010 & $\begin{array}{l}\text { Categories: white, black, yellow, brown and indigenous. Introduced the question "Do you consider yourself indigenous" } \\
\text { only for people living on indigenous lands and had not declared as indigenous question of color/race. }\end{array}$ \\
\hline
\end{tabular}

Fonte: IBGE, Caracterílsticas Gerais dos Indílgenas. Resultados do Universo. Rio de Janeiro, p1-245. 2012. Author herself. (1) Caboclo is a Brazilian Portuguese word derived from Old Tupi that indicates people of mixed indigenous and European descent. (2) Mulatto is a Brazilian Portuguese of mixed white and black ancestry. Note: In 1940 and 1950 censuses, it investigated the spoken language for people who do not usually spoke Portuguese at home. So there was the possibility to identify groups of individuals who used indigenous languages.

From a demographic point of view, it was important to understand the high growth experienced by the population who self-classified as indigenous between the censuses of 1991 and 2000, as well, that population would be identifying as indigenous and the trend of population growth would continue in the period 2000/2010. It should be noted that the indigenous population counted in the country in 2010 was around 900,000 inhabitants and growth rate of the urban areas compared to 2000 generally was negative, but in rural areas the population growth was significant, however, with less intensity than the previous period, 1991-2000.

\section{Advances in research of indigenous population}

The information for ethnic groups and language spoken among other characteristics are utmost importance to characterize the indigenous reality of any country. In the preparation of ethnic and linguistic research on Census 2010, IBGE counted on the collaboration of researchers linked to the Working Group Demography of Indigenous Groups of the Brazilian Association of Population Studies (ABEP), the Brazilian Anthropological Association (ABA), the Brazilian Association of Post-Graduate Collective Health (ABRASCO), the National Indian Foundation (FUNAI), the National Health Foundation (FUNASA), the Working Group the Linguistic Diversity (GTDL), coordinated by the National Institute of Historic and Artistic Heritage (IPHAN) of the Ministry of Culture, among others.

\subsection{Improvement of territorial base ${ }^{1}$}

The integration of cartographic bases of the IBGE with the National Indian Foundation (FUNAI) has been crucial to the applicability of the appropriate questionnaire on Indigenous Lands, by coincidence the limits of the census sectors with the Indigenous Lands. The 2010 Census Territorial Base was fully digital. With the Global Positioning System (GPS), it was possible to do georeferencing: the collection of all units in rural areas; of all establishments agriculture; of health, and educational, besides allows monitoring of the geographical coverage. To define the enumeration area ${ }^{2}$

\footnotetext{
${ }^{1}$ Territorial Base is a set of maps and records that represent the country in its various clippings - the cities with their urban and rural areas, districts, villages, and special areas of conservation units, indigenous lands etc. http://saladeimprensa.ibge.gov.br/sala-deimprensa-publicacoes/guia-das-atividades-de-geociencias/sobrebase-territorial.html.

${ }^{2}$ Enumeration area is the territorial unit established for purposes of cadastral control, formed by continuous area, located in a single urban or rural context, with size and number of households that allow the survey by a census taker. Therefore, each enumerator shall collect information with the goal of coverage of the enumeration area assigned to it.
} 
the network of agencies and the IBGE State Units coordinated by the technical staff. In Rio de Janeiro organized, analyzed and incorporated the information from various government agencies, which to the topic Indigenous Land is the National Indian Foundation (FUNAI), responsible for establishing and implementing the Brazilian Indigenous Policy in compliance with that determines the Brazilian Federal Constitution of 1988 [3].

For purposes of data collection and analysis of the results of the 2010 Population Census, the number of Indigenous Lands was formed by those where the land situation $^{3}$ was declared approved, regulated and acquisition process as an indigenous reserve until the date of December 31 2010, year of the census. The number of enumeration area that make up the group of Indigenous Lands recognized in any of the four situations totaled 2830 , with the majority, $87.7 \%$, belonging to the set of lands with land classified as "regularized" (Table 2).

\subsection{Importance of technology (Mobile Capture Devices - DMC)}

Brazil is an extremely large country, the utilization of specific geographic information technology, in-

\footnotetext{
${ }^{3}$ Indigenous Lands is a portion of the national territory, owned by Union inhabited by one or more indigenous peoples, he (s) used for their productive activities, indispensable to the preservation of environmental resources necessary for their welfare and necessary for its physical and cultural reproduction, according to their uses, customs and traditions. The right of indigenous peoples to their traditional occupation of land is configured as a primary law and, consequently, the administrative procedure for demarcation of indigenous lands is of a purely declaratory nature. Therefore, the indigenous land is not created by constitutive act, but recognized from technical and legal requirements under the Federal Constitution of 1988 and the phases of the demarcation procedure are defined by act of the President and consist of:

In studies: Conducting anthropological studies, historical, land, mapping and environmental factors that underlie the demarcation of the indigenous land.

Delimitadas (Term specific): Land that had the completion of studies published in the Official Gazette by FUNAI and are under review by the Ministry of Justice for shipping Declaratory Order of Possession Indigenous Traditional.

Declared: Lands who obtained the expedition Declaratory Ruling and are authorized to be marked.

Approved: Lands that were marked and had its limits approved by the president.

Regularized: Lands that after the approval of their limits, have been registered at the notary on behalf of the Union and Union Heritage Service.

Indigenous Reserves: These are lands donated by third parties, acquired or expropriated by the Union which are not confused with the traditional ownership and, therefore, are not subject to the above procedure. http://www.funai.gov.br/index.php/2014-02-07-13-24-32.
}

Table 2

Number of indigenous lands and surface, according to the legalized land situation Brazil - 2010

\begin{tabular}{lrr}
\hline \multirow{2}{*}{ Legalized land situation } & \multicolumn{2}{c}{ Indigenous lands } \\
\cline { 2 - 3 } & Number & Surface (ha) \\
\hline Total (1) & 505 & 106739926 \\
Declared & 49 & 2689068 \\
Homologated & 27 & 4761768 \\
Regularised & 405 & 99240743 \\
Being acquired as Indian Reservation & 24 & 48347 \\
\hline
\end{tabular}

Source: National Indian Foundation. (1) Exclusive Indigenous Lands Quixabá Fazenda Pedrosa and Tekohá Itamarã. Note: Upon considering the land being studied and defined, pass the 687 indigenous lands, with total area of $108629852 \mathrm{ha}$.

cluding the Mobile Capture Devices - DMC, was extremely important in the 2010 Census. In census literature, ethnic groups and language spoken in the housing unit these are variables considered topics difficult to measure, in addition, Brazil has a huge ethnic and linguistic diversity. Thus, mobile technology has played an important role in the deployment and improvements capture process of indigenous data in the census using Mobile Capture Devices (DMC), i.e., the replacement of the paper questionnaire by the electronic enabling the incorporation of descriptors databases with names of about 500 ethnic groups and 300 indigenous languages so that the enumerator could be guided.

To capture of ethnic groups and languages spoken, the open question and the possibility of involvement of errors by enumerators was very large, mainly because there was no specific training for those who would administer the census within indigenous lands. The different languages spoken by indigenous groups were regarded as a major obstacle to the interviews and the DMC was a great ally.

In addition to being essential equipment in the reduction, in general, the time dissemination of results; facilitated the procedures of selection of the sample questionnaires, and the draw of housing units conducted automatically. There was undeniably an increase the quality of information, with immediate critical at the time the data were collected, as well as, reducing significantly the errors affected by enumerators in both the filling obligatory questions as to control the filling by automatic skip patterns.

\subsection{Data collection}

The 2010 Census implemented within Indigenous Lands adapted questions related to both housing unit characteristics as the individual, in order to better characterize the demographic profile of the indige- 
nous population. Collection of information for the 2010 Census was accomplished by IBGE census takers with two questionnaire models: a "Basic Questionnaire" for housing units not selected on a sample basis and containing questions regarding characteristics of the housing unit and its residents that were investigated for 100 percent of the national population, and a "Sample Questionnaire" with additional detailed questions regarding the housing unit and its residents, addressing such themes as religion, migration, education, fertility, nuptiality, labor, and income, among others. Both questionnaires were applied within the Indigenous Lands.

\subsubsection{Housing characteristics}

For the census, housing unit was defined as the place with the purpose of residence or housing, which is divided into two types, particularly "occupied permanent and improvised" and collective [4]. Specifically, to the occupied permanent private housing units were investigated only within the following Indigenous Lands:

a) The various housing unit types was introduced the category "long house". 4

b) In the question "the predominant material of external walls" category has been added "without wall."

c) In the water supply used at home were included the categories "well or spring in the village" and "outside the village".

d) As the housing characteristics are investigated only for occupied permanent private housing units, it is essential that the classification as to their types is proper because in Brazilian Indigenous Lands are housing units with many indigenous inhabitants, the so-called "malocões" which could be mistaken for collective ${ }^{5}$ housing units, this information was controlled in the 2010 Census and frequencies have been significantly reduced. Yet Indigenous Lands as Rio Guaporé and Sagarana, located in the state of the State of Rondônia, housing units were mostly classified as collective, making it impossible to fill the housing unit characteristics.

\footnotetext{
${ }^{4}$ Indian housing rustic features, can be simple and wall; small, made from tree branches and covered with straw or leaves; or large hut made of bamboo and driftwood, covered with dry palms or straw, used as housing for several indigenous families.

${ }^{5}$ It is an institution or establishment where the relationship between the people in it were, living or not, on the date of reference, was restricted to administrative subordination standards.
}

\subsubsection{Characteristics of residents}

The methodology for collecting data on race/color in the Brazilian census is based on spontaneous individual statement and is the requirement of the formulation where the person has to self-identify according to self-perception [5]. The experience of the country and the implementation of self-identification methodology in capturing the indigenous population date since 1991 when it was incorporated more category to the four existing (white, black, yellow and brown) in the category of color/race.

Were introduced in the Residents Features the questions:

a) "Do you consider yourself indigenous?"6 Which was intended for residents in Indigenous Lands who did not classify him or herself as indigenous in the color/race question. In observation of the pilot tests of the 2010 Population Census, carried out in indigenous territories, a considerable number of indigenous no longer considered as such the question of color/race, ranking in the other categories of question, causing loss of information relating to ethnicity and language spoken.

b) "What ethnic group or people do you belong to?" For people who declared themselves indigenous in color/race question and also for residents in Indigenous Lands who declared in different category of indigenous in the color/race question, since it responds affirmatively to the question "Do you consider yourself indigenous?". To the extent that the enumerator typed the first three letters was open a list of all the possibilities of ethnic groups who could be found in Brazil within the digital questionnaire (DMC). The Census 2010 revealed that in Brazil were declared 305 ethnic groups, the ten largest indigenous group totaled 284,000 , representing a third of the total indigenous population in the country (Fig. 1). In the classification of the item they were considered beyond the declared ethnicity; indigenous groups in other countries; not determined; no definition; do not know and, no declaration. The list of "ethnic groups from other countries" was developed based on the results of censuses of the countries round 2000 where the reported ethnic groups and their respective frequency was observed in each country. Ethnic group was con-

\footnotetext{
${ }^{6}$ Indians considered themselves according to their traditions, customs, culture, ancestors, and so on.
} 


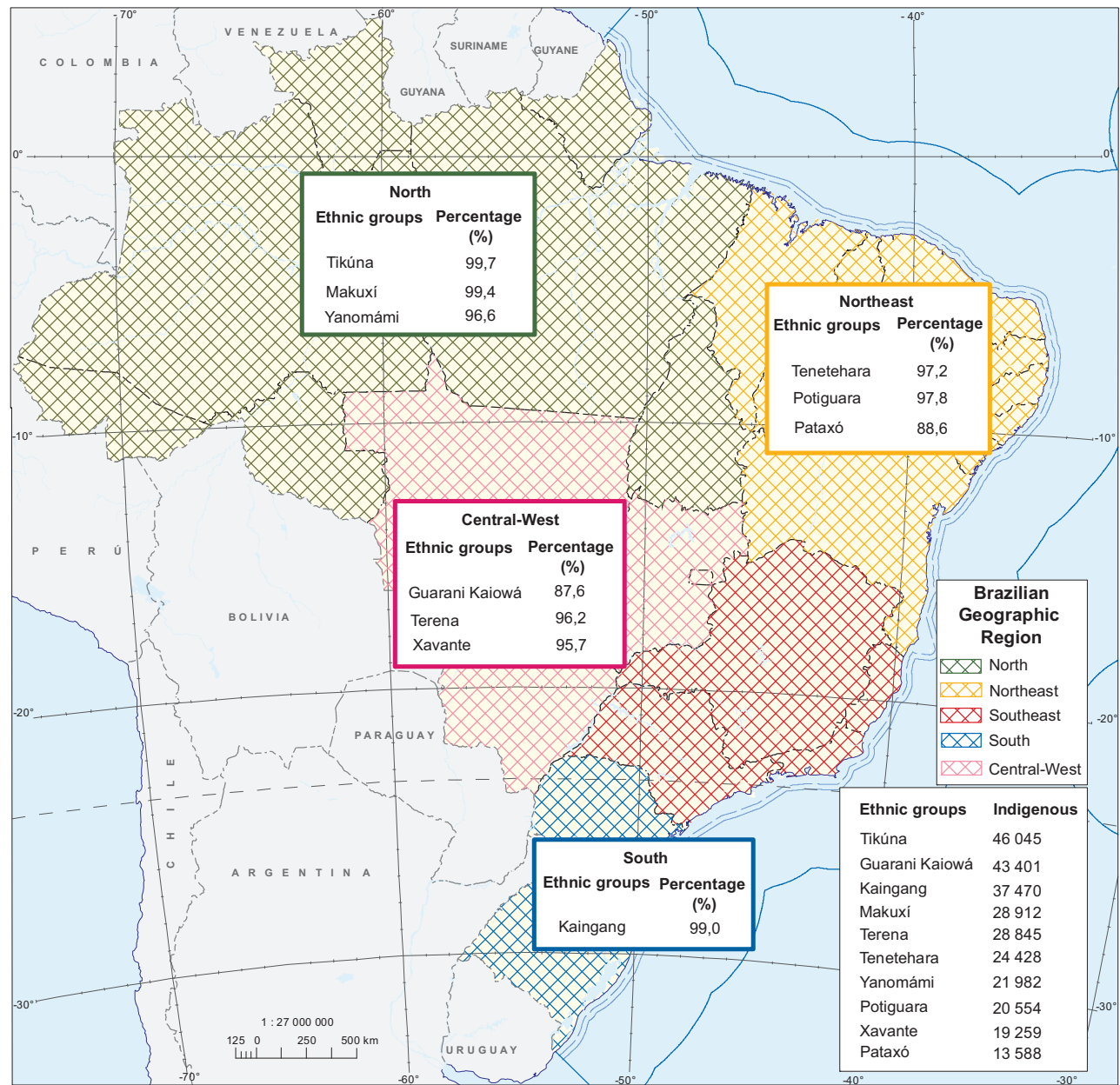

Source: IBGE, 2010 Brazilian Population Census.

Fig. 1. Largest ethnic groups in Brazil and percentage in the Brazilian Geographic region.

sidered "not determined", in case of statements such as: cacique, shaman, animal or plant names, Indigenous Lands, villages, trunk and language families, among others. For some cases of Indigenous Lands and villages it was identified some ethnic groups. For the "no definition", declared names of 26 Federation Units and Federal District (Brasília), municipalities, maroon, and gypsies, among others. There was a possibility of the respondent state that did not know the name of the ethnic group with the prediction of a code for "do not know" within the DMC, but also do not want to inform, thus getting the question blank.

c) For languages spoken, the census investigated, "Do you speak indigenous language in the housing unit? (Including the use of sign language), if positive, which ones"? And "Do you speak portuguese in the housing unit? (Including the use of sign language)?", How to collect data on indigenous languages of the Census 2010 was by two items the first of them wondered whether indigenous or not spoke an indigenous language, if the answer was positive was asked what language the name, can be answered up to two spoken languages. The Census 2010 revealed that in Brazil were declared 274 indigenous languages and, indigenous persons reported speaking two or more languages. To the extent that the enumerator typed the first two letters was open a list of all the possibilities of indigenous languages spoken by ethnic groups that inhabit or have inhabited Brazil within the digital questionnaire (DMC). Language is considered the second most 


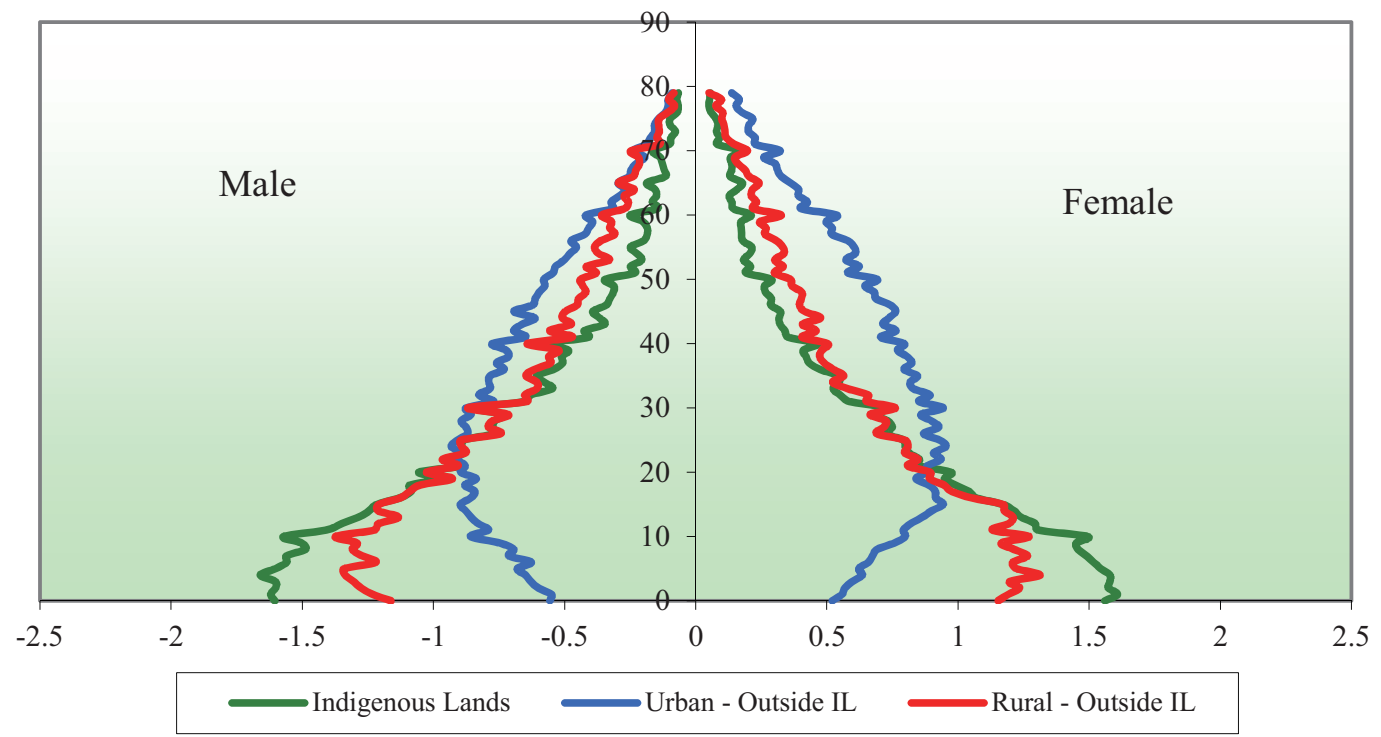

Source: 2010 Brazilian Population Census.

Fig. 2. Indigenous population pyramids Brazil -2010.

used criteria in the censuses of various countries to identify indigenous population. According Peyser and Chackiel [6,7], it is common to attribute to the language spoken the leading character among the other "cultural" events, since it is an important means by which to transmit culture. Some questions deserve to be considered, the first concerns the strong process of disappearance of indigenous languages, for residents Indians in urban areas, where children are not exposed to their native language at home and thus do not become fluent in indigenous languages. Basic education in urban schools do not include learning the indigenous language, and continuous interaction with non-indigenous population [8,9], and the second refers to the more difficult to understand the answer because enumerator were not necessarily indigenous, so the language barrier can be considered as a factor for not total identification of indigenous languages in rural areas.

d) The question "Has your birth been registered?" for children up to 10 years of age was included for the first time in the basic questionnaire of the 2010 Population Census and are investigated categories was the administrative registration of indigenous birth (RANI), this option was only available to people who declared or considered themselves indigenous, besides birth certificate at registry office and certificate of live birth at hos$\mathrm{pital} / \mathrm{maternity}$. e) On the topic nuptiality, specifically, in the question "Do you live with a spouse or partner (a)?", identified the name of the spouse or partner (a), and was completed for women aged 10 or older who were not spouses or heads of housing unit, enabling the identification of indigenous polygamy (specifically polygyny), that is, unions with more than one spouse, which is a feature of some indigenous groups in Brazil.

\section{Demographic and socioeconomic aspects [10]}

With the results of the 2010 Population Census it was possible to classify the indigenous resident in Brazil in three different configurations of age structure, possibly resulting from distinct fertility patterns that occur unevenly for socioeconomic groups distinct, as well as in different geographic regions, i.e., the indigenous peoples living on Indigenous Lands; those descendants of indigenous groups living in urban areas outside of Indigenous Lands, and indigenous people living in rural areas outside the Indigenous Lands, which in many cases would include the indigenous territories still in the land regularization process. The demographic characteristics of these three population groups are distinct, as age pyramids suggest (Fig. 2), and urban indigenous outside the indigenous territories have a more aged structure with a median age of 31.2 years, nearly twice those of indigenous peoples living on indigenous lands, it was 17.4 years old. 
Table 3

Demographic and socioeconomic indicators of Brazilian Population, indigenous and total, by geographic location - Brazil - 2010

\begin{tabular}{|c|c|c|c|c|c|c|}
\hline \multirow[t]{4}{*}{ Demographic and socioeconomic indicators } & \multicolumn{3}{|c|}{ Indigenous } & \multicolumn{3}{|c|}{ Total Brazilian Population } \\
\hline & \multicolumn{3}{|c|}{ Geographic location } & \multicolumn{3}{|c|}{ Geographic location } \\
\hline & \multirow{2}{*}{$\begin{array}{r}\text { Indigenous } \\
\text { lands }\end{array}$} & \multicolumn{2}{|c|}{ Outside Indigenous Lands } & \multirow[t]{2}{*}{ Total } & \multirow[t]{2}{*}{ Urban } & \multirow[t]{2}{*}{ Rural } \\
\hline & & Urban & Rural & & & \\
\hline Population & 517383 & 298871 & 80663 & 190755799 & 160925804 & 29829995 \\
\hline Sex ratio $(1)(\%)$ & 106.8 & 91.6 & 109.1 & 96.0 & 93.4 & 111.1 \\
\hline \multicolumn{7}{|l|}{ Composition of the population (\%) } \\
\hline Under 15 years & 44.6 & 21.1 & 37.0 & 24.1 & 23.2 & 28.6 \\
\hline $15-64$ & 51.3 & 71.0 & 57.2 & 68.5 & 69.4 & 63.9 \\
\hline $60+$ years & 4.1 & 7.9 & 5.8 & 7.4 & 7.4 & 7.5 \\
\hline \multicolumn{7}{|l|}{ Dependency ratio (2) (\%) } \\
\hline Total & 94.9 & 40.8 & 74.8 & 45.9 & 44.1 & 56.5 \\
\hline Children ( $0-14$ years old) & 86.9 & 29.7 & 64.7 & 35.1 & 33.5 & 44.8 \\
\hline Older persons ( 65 years or over) & 8.0 & 11.1 & 10.1 & 10.8 & 10.6 & 11.7 \\
\hline Aging index (3) (\%) & 9.2 & 37.4 & 15.7 & 30.7 & 31.7 & 26.1 \\
\hline Median age & 17.4 & 31.2 & 21.3 & 29.4 & 29.8 & 26.8 \\
\hline $\begin{array}{l}\text { Literacy rate of persons aged } 15 \text { years or } \\
\text { older }(\%)\end{array}$ & 67.7 & 88.5 & 71.4 & 90.4 & 92.7 & 76.8 \\
\hline $\begin{array}{l}\text { Percentage of children } 10 \text { years of age with } \\
\text { registry office birth }(\%)\end{array}$ & 63.0 & 90.9 & 80.8 & 98.1 & 98.5 & 96.7 \\
\hline \multicolumn{7}{|l|}{$\begin{array}{l}\text { Percentage of } 10 \text { or more years of age by } \\
\text { type of income }(\%)\end{array}$} \\
\hline In cash, products or goods & 34.2 & 63.9 & 45.6 & 62.9 & 64.4 & 54.6 \\
\hline Only benefits & 8.1 & 1.5 & 6.3 & 1.5 & 1.1 & 3.8 \\
\hline No income & 57.6 & 34.6 & 48.1 & 35.6 & 34.5 & 41.6 \\
\hline
\end{tabular}

Source: IBGE, 2010 Brazilian Population Census. (1) Sex ratio is calculated as the number of males per one hundred females in a population. (2) Dependency ratio is the number of persons under age 15 plus persons aged 65 or older per one hundred persons 15 to 64 . It is the sum of the youth dependency ratio and the old-age dependency ratio. (3) Aging index is calculated as the number of persons 65 years old or over per hundred persons under age 15 .

Another important difference concerns the basic literacy rate of indigenous people aged 15 or more, as $88.5 \%$ were literate at the time of the 2010 census, while on Indigenous Lands only $67.7 \%$ were in this condition. With regard to birth registration of indigenous children below age 10 year, $90.9 \%$ of residents in urban areas is registered in "civil registry office", while on Indigenous Lands was observed in $63.0 \%$ of indigenous children. For indigenous people 10 years or older, $63.9 \%$ who received cash, products, goods or benefits with the development of an economic activity, contrasting with the $34.2 \%$ of Indigenous Lands. In most of the above indicators, residents in rural areas outside the indigenous territories, are in an intermediate situation, that is, between the indicators of residents in the Indigenous Lands and urban areas outside of Indigenous Lands, as can be seen in Table 3. In comparison with the data of the total Brazilian population, indigenous people living in urban areas outside of ILs already have indicators that residency in urban areas result in increased access to basic public health services. While, the other for areas (Indigenous Lands and Rural Outside ILs) still lack is high.

\section{Conclusions}

During the census planning in 2010, the demands on the research of the indigenous population was to the effect that indigenous peoples were collected in every housing unit and not by sample; that ethnicity and the language spoken by indigenous were captured. Another important demand of the researchers was that a conceptual adaptation was performed, that is, the variables investigated in the sample questionnaire were more harmonious with the characteristics of the population living on Indigenous Lands. A recommendation on the preservation of the indigenous was the non-removal of groups isolated, depending on the policy for conservation without forcing contact, the IBGE study the possibility of adopting, where possible, indigenous enumerators within Indigenous Lands. Of all the recommendations, although all possibilities have been studied, we could not have exclusively indigenous enumerators.

In the International Conference on Population and Development (CIPD-PA) [11] a themes agenda on population and development was established and recommended specifically for indigenous and Afro-descendant populations that future efforts should focus on the 
recognition of the importance of multiculturalism in society; promote measures to reduce racial and ethnic disparities and ensure the full exercise of individual and collective rights of these groups with equal opportunities, in particular as regards the return of ancestral lands and territories, access to health, nutrition and education [12] and therefore, studies should be directed in the interpretation of existing census data, but also in the continuation of discussions about the improvement for their capture in housing unit surveys, in order to contribute to greater visibility of these segments population.

\section{Acknowledgements}

We thank Zélia Bianchini, Jaqueline Manhães, Ricardo Santos and José Sena for his careful reading of the manuscript and useful comments and the geographer Jorge Kleber Silva for preparing the map.

\section{References}

[1] S. Schkolnik and F. Del Popolo, Los censos y los pueblos indígenas en América Latina: Una metodología regional, revista Notas de Población. CELADE - División de Población de la CEPAL, Santiago de Chile 79 (2005), 101-132.

[2] N.O.M. Pereira, Inovações na pesquisa do indígena do Censo Demográfico 2010 do Brasil, Trabalho apresentado no V Congresso da Associação Latinoamericana de População, Montevideo, Uruguai, 23 a 26 de outubro de 2012.

[3] IBGE, Características Gerais dos Indígenas. Resultados do Universo. Rio de Janeiro, p1-245, 2012.

[4] IBGE Censo demográfico, Manual do Recenseador, CD 1.09, Rio de Janeiro, (2010). Disponível em: http://biblioteca.ibge. gov.br/visualizacao/instrumentos_de_coleta/doc2601.pdf.

[5] A. Giusti, Argentina: censo 2001, alternativa de abordaje de la problemática indígena. Trabalho apresentado no I Encuentro internacional todos contamos: Los grupos étnicos en los censos, Cartagena de Índias, Colômbia; 2000.
[6] A. Peyser and J. Chackiel, La población indígena en los censos de América Latina. In Estudos Sociodemograficos de Pueblos Indígenas. Centro Latinamericano de Demografía CELADE, Santiago de Chile; 1994.

[7] A. Peyser and J. Chackiel, La identificación de poblaciones indígenas en los censos de América Latina. In: AMÉRICA Latina: aspectos conceptuales de los censos del 2000. Santiago de Chile: Naciones Unidas, División de Población 1999; pp. 353-363. Disponível em: <http://www.eclac.org/publica ciones/xml/6/4436/ lc11204e.pdf>. Acesso em:ago. 2009.

[8] S. Schkolnik, Algunos interrogantes sobre las preguntas censales para identificar población indígena en América Latina, documento presentado al Seminario "Todos contamos: los grupos étnicos en los censos", I Encuentro Internacional, Cartagena de Indias, Colombia, 2000.

[9] N.O.M. Pereira, Os indígenas nas informações censitárias: potencialidades e limitações com base em um estudo de caso sobre os Xavante, Mato Grosso. Tese apresentada com vistas à obtenção do título de Doutor em Ciências na área de Saúde Pública. Rio de Janeiro, Brasil, 2011.

[10] N.O.M. Pereira, Indígenas residentes nas áreas urbanas do Brasil: uma análise das etnias oriundas de outros paises. VI Congresso Latinoamericano de População, "Dinámica de población y desarrollo sostenible con equidad", realizado em Lima, Perú, 12 a 15 de agosto de 2014.

[11] S. Cavenaghi, A dinâmica populacional e a agenda de população e desenvolvimento sustentável. In: Cairo+20: Perspectivas de la agenda de poblción y desarrollo sostenible después de 2014. Wong, Laura Rodríguez; Alves, José Eustáquio; Vignoli, Jorge Rodríguez; Turra, Cássio Maldonado (Orgs.). Serie Investigaciones $n^{\circ} .15$, Alap Editora $-1^{a}$. Edição, Rio de Janeiro, 2014

[12] A.L. Freitez, La agenda de población y desarrollo 20 años después de la CIPD: reflexiones desde la Asociación Latinoamericana de Población. In "Cairo+20: Perspectivas de la agenda de poblción y desarrollo sostenible después de 2014”. Wong, Laura Rodríguez; Alves, José Eustáquio; Vignoli, Jorge Rodríguez; Turra, Cássio Maldonado (Orgs.). Serie Investigaciones $n^{\circ} .15$, Alap Editora $-1^{a}$. Edição, Rio de Janeiro, 2014 